\title{
Mentoring for Personal and Professional Success: Personal Reflections*
}

\author{
H. Wallace Goddard \\ University of Arkansas Cooperative Extension Service
}

\begin{abstract}
*Please address all correspondence to: Dr. H. Wallace Goddard, Certified Family Life Educator, Professor, Family Life, University of Arkansas Cooperative Extension, 2301 S. University, Box 391, Little Rock, AR 72203; Phone: 501671 2104; Fax: 501 671-2294; Email: wgoddard@uaex.edu.
\end{abstract}

Mentoring has both a narrow and a broad meaning. In the professional world, a mentor is a wise and experienced adviser-someone who supports us as we grow toward the full measure of our professional aspirations. Yet a mentor is also a counselor and teacher. This kind of mentoring happens any time a respected person helps us make course corrections in our development.

It seems that we are not intentional about seeking or providing mentoring. It often seems to be the result of happenstance. I did not feel mentored through public and undergraduate education or even a Master's degree. When I started a job as a high school teacher there was never a hint that some conscious and deliberate guidance would be provided for a green teacher. I suppose the default assumption was that, if you have finished college, you are ready for the realities of the classroom. I believe that assumption is unjustified.

After a dozen years in public education, I returned to graduate school for a $\mathrm{PhD}$ in Family and Child Development. In that program, I received some of the best mentoring I have received. In the twenty-plus years since then, I have tried to be more intentional about mentoring, and I have experienced how beneficial it can be.

I often am surprised to realize that I assume-in spite of contrary experience - that my students and colleagues know everything I know. I assume that I have nothing useful to share with them. I should know better. Each of us has a set of experiences that can benefit those with whom we work. I have experience I can share with you. You have experiences that can benefit me. Mentoring can make a big difference.

\section{Early Mentoring}

My first recollection of anything resembling mentoring was from my fifth grade teacher, Rhea Bailey. I do not remember many details about her teaching. What I do remember is that she valued me. Though I was a goofy and thoughtless little boy, she made it clear that I was important to her. On my report card she wrote to my parents: "It is a pleasure to have Wallace in my class." I glowed.

On the last day of the school year, Mrs. Bailey sent me home with a sealed envelope. She told me to open it when I was with my parents. I was tempted to panic. What if she reported the accumulated misdeeds of the year to my parents? But, being a dutiful little boy, I did as I was told. When I opened the envelope, my 
parents and I found two things. On a half-sheet of lined paper, she wrote: "Dear Wallace, It has been such a joy to teach you. I expect great things of you, Wallace, because the Lord has blessed you with many talents. Let me know what you are doing as the years go by. Sincerely, Mrs. Rhea Bailey."

The other item in the envelope was a piece of construction paper cut out in the form of a state-fair ribbon. On the circle she had written my name: Wallace. On each of the two tails she had written a quality she saw in me: Scholarship; Personality. As you might imagine, both items from Mrs. Bailey are still in my childhood scrapbook. I am still warmed by her support. Mrs. Bailey shined a bright light into my life that continues to guide my path.

Good mentoring is more than technique. The heart of it is support and encouragement. It is based on relationships.

I hardly expected that she would teach me again decades after elementary school. Actually, Mrs. Bailey was long since departed when I wrote a magazine article that told about her. One of her descendants called me and I gladly shared with the family my reminiscences and copies of her kind note and "award." In return, the family sent me a copy of her biography. It was only then that I discovered that Mrs. Bailey was a young woman with three young children when her husband spiraled into a brain cancer that quickly took his life. She found herself a grieving and unprepared widow. She cared for her children and put herself through the university. And she became a teacher at Libby Edward Elementary School. Little did I know or appreciate, when I was a child, that Mrs. Bailey had burdens of her own and yet managed to give so graciously to her students.

Decades after I sat in her classroom, I was once again mentored by Mrs. Bailey. I suspect that the best mentors are those who, like Mrs. Bailey, have great compassion--whether because of pains they have suffered or natural endowment. I suspect that I taught in the public schools for a dozen years in part because of people like Mrs. Bailey.

\section{Later Mentoring}

In my first university job, my department head assigned me a mentor. He dutifully took me on tour of campus and explained in great detail the expectations of the job. As he described the requirement to get grants, conduct research, publish journal articles, teach classes, mentor graduate students, and create outreach publications, my spirits sagged. My mentor did not give me any tips for the strategic management of the demands. He did not do any assessment of my resources, hope,s or goals. He merely painted a detailed picture of an academic superhero and left me to figure out how to fly. I became depressed. He was quite unaware of my discouragement.

I do not begrudge my mentor his inability to meet my needs. No one mentored him on how to mentor-which makes this special issue on mentoring all the more valuable. Maybe we should better equip those we ask to mentor. Maybe only those who have a heart to mentor and a talent for building relationships should take on the role. In the paragraphs ahead, I hope to provide my own suggestions for mentoring. 


\section{My Approach to Mentoring}

I will leave to my colleagues who know far more about the research on mentoring (Ragins \& Kram, 2008) to represent that research. I would like to describe my own model for effective mentoring. I call my approach Gifts, Fire, and Covenants. It is the culmination of years of experience trying to build my own career and my effort to help others build theirs.

\section{Gifts}

All of us have specific gifts, talents, abilities, strengths, and resources. A good professional and a good mentor should know what his or her unique resources are. I suspect that those who are most self-aware are most able to help those they mentor unearth their gifts. While one model of mentoring suggests that gurus dispense sage advice to neophytes, the model that works best for me is more interactive and more like relationships in general. I think that the ideal mentor opens the library of his or her life experience and guides the mentee to learn from volumes of experience.

As I got acquainted with graduate students at Auburn University who were seeking mentors (both for thesis projects and assistantships), I tried to be transparent to help them make good choices. I told them about my areas of research (teen behavior), my areas of expertise and interest (parenting, healthy marriage, personal well-being), and my working style ("I am a self-starter and probably work best with students who are self-starters."). I told them that my cheerfulness should not be mistaken for easiness; I like quality work.

I invited students to tell about their accomplishments, abilities, research interests, working style, and career goals. I tried to assess our goodness of fit. I described what I saw as the synergies and the challenges in any collaboration.

This may sound coolly objective, almost mechanical. That is not accurate. I subscribe to a version of the fulfillment model of personality (Maddi, 1989.). I believe that 1). all people are equipped with gifts or strengths, 2). our strengths are connected to our weaknesses (energetic people are also likely to be impatient, etc.), and 3). strengths flourish, grow, and achieve in an environment that appreciates and utilizes them.

Effective mentors have probably had many experiences that have helped them discover and understand their unique talents. Some may have invested many hours coming to understand their own strengths through objective measures. This may include identifying personality resources using assessments such as MyerBriggs Type Indicator or True Colors. It may include strength assessments such as the Values in Action Signature Strengths Survey (VIASSS at www.authentichappiness.org). Mentors may then invite mentees to use similar tools for their own discovery of their gifts. Objective measures can provide valuable input.

Along with objective assessments, mentors may use the processing of previous experiences to unearth mentees' ideal future. They might explore the answers to questions like: What projects have you most loved in the past? What 
tasks do you dread? When do you feel most competent? When are you in flow (Csikszentmihalyi, 1997)?

Whether mentors use established instruments or sustained dialogue to discern mentees' gifts, the foundation for effective mentoring is capitalizing on specific individual strengths. A good mentor does more than dispense generic good advice (though that has its place); the good mentor labors to understand the specific strengths and ideal environment for each potential mentee.

Perhaps a note about generic advice is in order. People who have been in any field for some years generally have picked up an understanding of the culture and its unwritten rules that have come to seem obvious to them. Yet those rules are not obvious to those who are new to the culture. Helpful mentors invite their mentees to talk about their plans and they help them navigate waters that are unfamiliar to them. Able mentors teach mentees about the unwritten rules of the culture. They help them understand the dynamics of the environment they are entering.

One of the dangers of mentoring is that we may try to impose our own styles and ambitions on those whom we serve. Or, in contrast, we leave them to find their own way. Neither is helpful. Let me illustrate.

In my first career, I taught high school physics and math. I remember walking along the hall of the high school early one school year with a visiting colleague. As we walked and talked, a student ran up to us and told me that the music teacher wanted him in his class and so he would have to drop my physics class. I was disappointed, but wanted to do what was best for the student. So I told him that I would like to have him in my physics class but would respect his decision. I felt noble that I had not pressured him toward my preferred outcome. As he dashed away, my colleague challenged me: "You really failed that kid when he needed you." I was surprised. "What do you mean?" He taught me a memorable lesson: "That kid was being pressured by a teacher. He needed you to help him make a decision that was right for him. As it is, he ended up in the class of the teacher who applied the most pressure. You could have help him explore which class best met his needs. You could have asked him about what he hoped to get from each class. You could have helped him assess how each would fit in his schedule and his future. You could have helped him identify his gifts and ways to use them. But you didn't."

He was right. I had stepped away from a mentoring opportunity. I had left the student to find his own way. One of the keys to effective mentoring is guiding mentees through questions about their gifts and the best ways to use them. I am glad for that lesson in mentoring.

\section{Fire}

The second element of my model of mentoring is "fire." While each of us has various durable dispositions and abilities, we also have episodic enthusiasm. We are excited about something. I call this fire.

For example, as a young professional with children at home, my keenest professional interest was in parenting. That was my focus, my fire. As the years have passed, my focus has turned to other areas such as the amazing discoveries 
in couple relationships and the new positive psychology. While there is something to be said for establishing a specific area of expertise, there is also merit in allowing our professional focus to grow and change along with our own growth and interests.

My friend and colleague Barbara Keil asks me the question, "In what area do you have the ability and interest to sustain you in becoming a world class contributor?" That is a good question. Although there are many areas where we can invest our energy and while some of them may offer greater opportunities for prominence, I recommend that we choose those areas that fit best with our energy.

To help our mentees discover their fire (or to discover our own), we can ask questions like: What subject is terribly exciting to you right now? What project or opportunity seems to fit perfectly with your fire?

Perhaps they will feel invited to create a parenting program, write a marriage book, or design a workbook for happiness. We pursue the project that uses our current fire.

The idea of fire does not excuse flightiness. A person who chooses a project should establish a goal and schedule that requires discipline and will culminate in a meaningful contribution. Yet the fire in our lives may be different at different times. It is my view that we will contribute the most if we are growing. This idea might be best expressed by the familiar maxim: "Why build these cities glorious if man unbuilded goes; In vain we build the work unless the builder also grows."

It was this principle of fire that moved me from teaching high school to studying family relationships. My fundamental gifts had not changed but my frontier for learning had. While changing careers certainly jolted my tidy career path (and retirement savings), it was a choice to invest in human capital. The decades of work in human development and family relationships have been inexpressibly satisfying and growth-promoting.

I am not recommending sporadic career changes. Many of the adjustments will be far smaller. I am recommending that we invite our own enthusiasm and need for growth into the life-decisions process. Whether we are refining our own career path or helping mentees with theirs, fire can make a meaningful contribution.

\section{Covenants}

This is the third process in my model of both personal growth and professional mentoring. Covenanting suggests to me that we make serious promises to ourselves and others to contribute to an area or project that fits with our gifts and follows our fire. This combines commitment with service. For example, our work team in the University of Arkansas Cooperative Extension Service explored the possibility of creating a different kind of ages and stages program. We gathered data about the need in the state. We examined the existing programs. We discussed the work necessary to create the program. We had the requisite gifts in our group including creative and practical types. We had the fire; the team was excited about the project. So we made a commitment. 
We hardly realized the hundreds of hours we would invest writing and refining the program we created. We spent many hours taking individual units and working as a team to refine them until we had created the program we wanted. Ultimately, we created a program called See the World Through My Eyes in which we invite adults who work with children to understand 21 normal developmental challenges of preschoolers from the children's point of view. The project required more time than any of us had anticipated - but we were committed. We had made a pact, or covenant, to work on the project until it was complete.

The work paid off. The program was awarded three gold awards by the Association for Communication Excellence, two for writing and one for design. This project had particular pertinence for mentoring since the group included a wide range of experience and training from a few months to decades. Mentoring can happen as an integral part of group work. And all of us learned from each other.

This experience underscores the reality that mentoring does not necessarily happen as a separate enterprise walled-off from normal professional activity. We invite mentees to work on papers with us. We invite less experienced colleagues to work on projects with us. We collaborate in many ways. Along the way we take time to share experiences one of us has had that could benefit others in the group. Quality mentoring involves thoughtful and specific investment in helping mentees cultivate an awareness of their unique talents, their specific opportunities, and their ideal professional path.

Wise mentors tune in to the gifts and abilities of their colleagues. Then sense the fire or enthusiasm that can be tapped and directed. And they help their colleagues make informed commitments for contribution. That is how gifts, fire, and covenants can help us mentor effectively.

\section{Conclusion}

I conclude by paying tribute to the mentor who did the most to transform me from a physics teacher to a family professional: Brent C. Miller, my major professor at Utah State University. In his own career, Brent was a productive scholar, a thoughtful colleague, and a warm supporter. In the early months of my Ph.D. program, Brent listened patiently and thoughtfully to my description of professional hopes and dreams - even though they were naïve and overambitious. He helped me think about priorities, and he created opportunities for me to write papers with him, and provide leadership to an NCFR project. As I wrote white papers then a prospectus and ultimately a dissertation, Brent responded to my writing with a flood of red ink. Yet his support and encouragement were so conspicuous and consistent that the red ink felt like a gift rather than an assault. He was not assaulting an inexperienced student but was investing in me and my future. As I finished my program, he helped me assess job options and prepare for interviews. In the early years of a job at Auburn University, he joined me in writing papers, designing my career, and celebrating my successes.

Brent saw my gifts, recognized my fire, and he made a covenant to help me develop professionally. What a difference a mentor can make! 


\section{References}

Csikszentmihalyi, M. (1997). Finding flow. New York: Basic Books.

Maddi, S. (1989). Personality theories. Chicago, ILL: Dorsey Press.

Ragins, B. R., \& Kram, K. E. (2008). The handbook of mentoring at work: Theory, research, and practice. Thousand Oaks, CA: Sage. 